\title{
Diversity of algae in a thallium and other heavy metals-polluted environment
}

\author{
Bartosz J. Płachno ${ }^{1}$, Konrad Wołowski ${ }^{2 *}$ Joanna Augustynowicz ${ }^{3}$ and Magdalena Lukaszek $^{2}$ \\ 1 Department of Plant Cytology and Embryology, Jagiellonian University in Kraków, Gronostajowa 9 St., $30-387$ Kraków, Poland \\ 2 Department of Phycology, W. Szafer Institute of Botany, Polish Academy of Sciences, Lubicz 46 St., PL-31-512 Kraków, Poland \\ 3 Faculty of Biotechnology and Horticulture, Institute of Plant Biology and Biotechnology, University of Agriculture in Kraków, \\ Al. 29 Listopada 54, 31-425 Kraków, Poland
}

Received 5 September 2014; Accepted 3 March 2015

\begin{abstract}
Thallium ( $\mathrm{Tl}$ ) compounds are extremely toxic to living organisms, including algae, but there is a dearth of basic information regarding the mechanisms of action of $\mathrm{Tl}$ in the environment and its effects on algae in natural conditions. This study examined algal diversity in an environment highly polluted by $\mathrm{Tl}$. Graniczna Woda stream is contaminated by $\mathrm{Tl}$ and other heavy metal compounds ( $\mathrm{Cd}, \mathrm{Pb}$ and $\mathrm{Zn})$. There we found 66 algae taxa representing five phyla, among which euglenophytes prevailed. We found that euglenophytes, including Phacus species, can survive and can show high species diversity in the presence of high $\mathrm{Tl}$ concentrations. The fact that these small organisms covered only by a pellicle are able to thrive in such inhospitable habitat, shows a great plasticity of these organisms. It is unclear whether the algae of Graniczna Woda stream have a broad tolerance to harmful conditions or rather represent new varieties/clones that evolved in metal-contaminated waters and are adapted to this environment.
\end{abstract}

Key words: Euglenophytes / $\mathrm{Cd} / \mathrm{Zn} / \mathrm{Pb} /$ thallium / water pollution

\section{Introduction}

Thallium (Tl), a metallic element placed in group 13 (formerly $3 \mathrm{~A}$ ) of the periodic table on account of its high density $\left(>11.6{\mathrm{~g} . \mathrm{cm}^{-3}}^{-3}\right.$, is classified as a heavy metal. Its name, from Greek, is connected with the green spectral line that identified this element (Fleischer, 1997). Tl in the environment exists at two oxidation states: the more stable $\mathrm{Tl}(\mathrm{I})\left(\right.$ e.g., $\left.\mathrm{Tl}{ }_{2} \mathrm{O}\right)$ and the less stable $\mathrm{Tl}(\mathrm{III})\left(\right.$ e.g., $\left.\mathrm{Tl}(\mathrm{OH})_{3}\right)$. The natural background level of $\mathrm{Tl}$ in the Earth's crust is put at $0.85 \mathrm{mg} . \mathrm{kg}^{-1}$, and its minerals, associated with $\mathrm{K}$ or $\mathrm{S}$, are quite rare but widespread. Its mean concentration in natural water systems is $10 \mathrm{ng} \cdot \mathrm{dm}^{-3}$ (Kabata-Penidias and Mukherjee, 2007). Under the quality standards of both the United States Environmental Protection Agency (EPA) and the Polish Ministry of the Environment, the maximum permitted concentration of $\mathrm{Tl}$ in surface waters is $2 \mu \mathrm{g} . \mathrm{dm}^{-3}$. Anthropogenic sources of Tl in the environment are related mainly to coal combustion and ferrous or nonferrous smelting (Peter and Viraraghavan, 2005). Commercial use of $\mathrm{Tl}$ is associated with the manufacture of refractive glass and formerly for pesticide production,

\footnotetext{
*Corresponding author: k. wolowski@botany .pl
}

and it is used as a radioisotope for scintigraphy (Kabata-Pendias and Mickherjee, 2007). Both Tl(I) and Tl(III) compounds are readily soluble and therefore bioavailable. $\mathrm{Tl}$ compounds are extremely toxic to living organisms. Its toxicity to mammals is higher than that of $\mathrm{Hg}, \mathrm{Cd}$ and $\mathrm{Pb}$ (Peter and Viraraghavan, 2005; Babula et al., 2008). Up to 1984, however, Tl was not considered an environmental pollutant. In Poland, research on the effects of $\mathrm{Tl}$ on biota started in the late 1990s, focused on plants and small mammals occurring in the vicinity of Olkusz, a highly industrialized area in southern Poland (e.g., Dmowski et al., 1998; Wierzbicka et al., 2004).

As with other heavy metals, the effect of $\mathrm{Tl}$ on organisms can be explained by its binding to - $\mathrm{SH}$ groups of cysteine residues in proteins, leading to changes in the activity of a broad range of enzymes. The most pronounced toxic effect of the $\mathrm{Tl}$ ion is related to the similarity of $\mathrm{Tl}(\mathrm{I})$ to the potassium ion, due to their similar chemical structure and properties. Monovalent Tl disrupts Kcontrolled activity of enzymes and membrane processes such as the mitochondrial respiratory chain, and also stabilization of ribosomes (Léonard and Gerber, 1997; Arzate and Santamaria, 1998; Peter and Viraraghavan, 2005). 


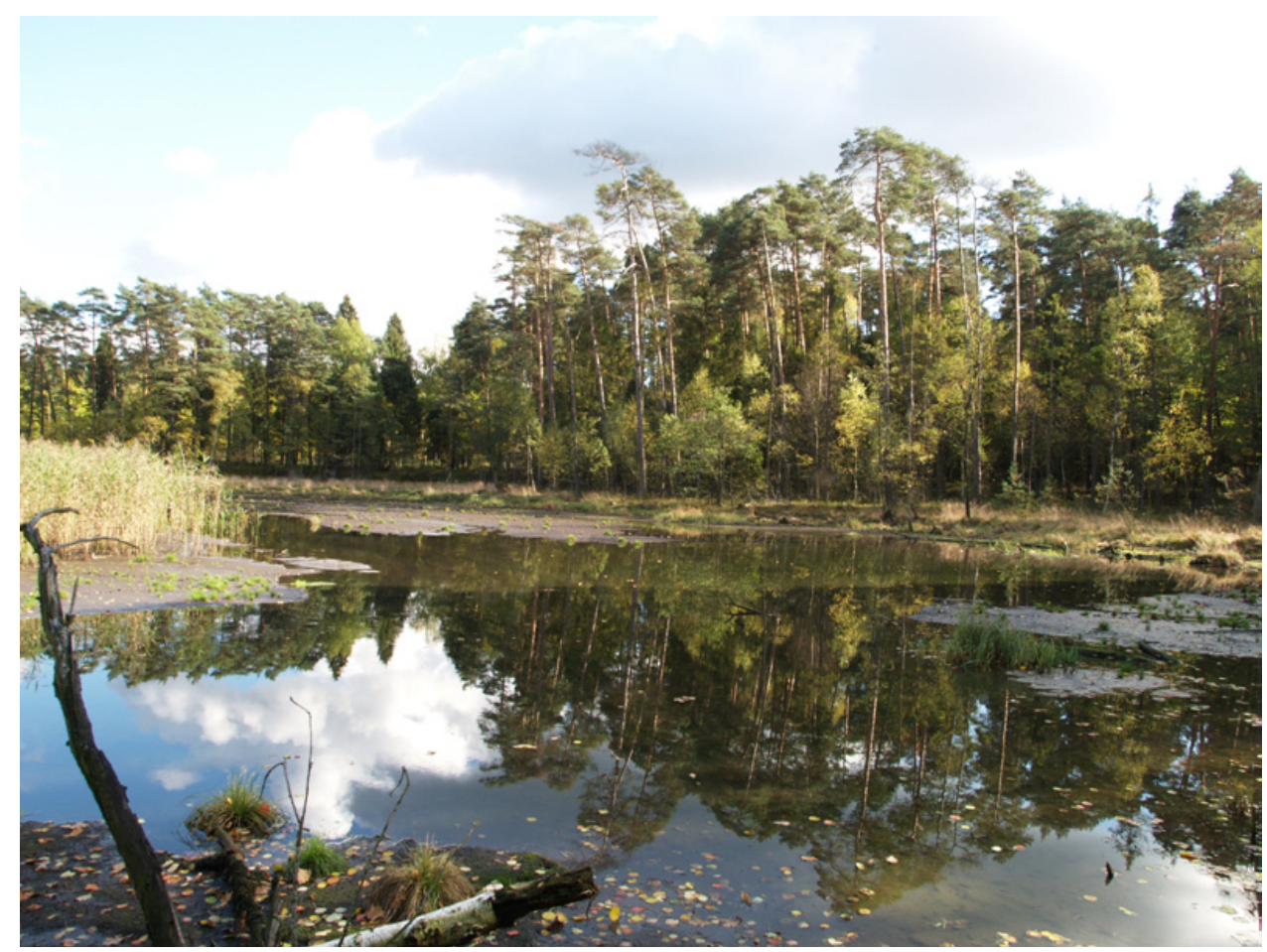

Fig. 1. Oxbow of Graniczna Woda stream in the former Dęby Boruszowickie Reserve.

Unlike for the heavy metals $\mathrm{Cd}, \mathrm{Pb}, \mathrm{Hg}, \mathrm{Ni}$ and $\mathrm{Zn}$, the literature contains little data on the effects of $\mathrm{Tl}$ on plants. Only three plant species have been classified as $\mathrm{Tl}$ hyperaccumulators, that is, plants able to accumulate $>100 \mathrm{mg} \cdot \mathrm{kg}^{-1}$ d.w. in natural conditions: Iberis intermedia Guersent, Biscutella laevigata L. (both from the Brassicaceae family) and Silene latifolia Poir. (Caryophyllaceae) (van der Ent et al., 2013). These are all terrestrial species originating from southern France. Studies showed that $\mathrm{Tl}$ can accumulate especially in plants of the Brassicaceae family (Leblanc et al., 1999; Al-Najar et al., 2005). There is far less information about aquatic vegetation in Tl-contaminated environments, although these organisms, immersed as they are, are far more exposed to harmful substances. In Synechocystis, Avery et al. (1991) demonstrated competition between $\mathrm{Tl}(\mathrm{I})$ and $\mathrm{K}$ ions, and Lustigman et al. (2000) showed Tl(I) toxicity to the cyanobacterium Anacystis nidulans (Richter) Drouet \& Daily and the chlorophyte Chlamydomonas reinhardtii P.A. Dang. Ralph and Twiss (2002) reported differential toxicity of $\mathrm{Tl}$ to the unicellular chlorophyte Chlorella, which depended on the oxidation state of the metal. They observed the same degree of Chlorella growth inhibition under treatment with $\mathrm{Tl}$ (III) at a dose of $2 \times 10^{-13}\left[\mathrm{~mol} . \mathrm{dm}^{-3}\right]\left(4.1 \times 10^{-2}\right.$ ng.dm $\left.{ }^{-3}\right)$ and with $\mathrm{Tl}(\mathrm{I})$ at a dose of $10^{-8}\left[\mathrm{~mol} . \mathrm{dm}^{-3}\right]\left(2.0 \mu \mathrm{g} . \mathrm{dm}^{-3}\right)$. They noted that $\mathrm{Tl}$ (III) toxicity was orders of magnitude greater than $\mathrm{Tl}(\mathrm{I})$ to this phytoplankton but that the bioavailability of $\mathrm{Tl}$ (III) was significantly limited, and pointed to the lack of fundamental information regarding $\mathrm{Tl}$ in the environment. In experiments on Lemna minor L., Tl(I) induced generation of reactive oxygen species, resulting in damage to DNA and cell proteins (Babić et al., 2009). The intrinsic toxicity of $\mathrm{Tl}$ and the mechanism of its transport through the cell membrane were investigated by Turner and Furniss (2012) in the marine alga Ulva lactuca $\mathrm{L}$.

Upper Silesia (southern Poland) is a highly contaminated mining and industrial region. Some watercourses in this area, including Graniczna Woda stream, are polluted by heavy metal compounds from chemical plants and mines. Graniczna Woda stream was polluted by chemical plants in the town of Tarnowskie Góry and by zinc smelters in the town of Miasteczko Śląskie (Reczyńska-Dutka, 1986). In our latest work (Augustynowicz et al., 2014), we conducted the Microtox ${ }^{\circledR}$ toxicity test on the Graniczna Woda strem and showed that studied water exhibited second class of acute toxicity. In the above-mentioned work, we also found high Tl pollution of the water in Graniczna Woda stream with almost complete absence of higher aquatic plants in its streambed. In the present study, we examined there the diversity of algal flora. In an unpolluted location in this area we had recorded a rich algal flora in an earlier study (Wołowski et al., 2013a).

\section{Material and methods}

\section{Study site}

Material was obtained from Graniczna Woda stream and its oxbow (Fig. 1) in the former Dęby Boruszowickie Reserve near Tarnowskie Góry (Upper Silesia, Poland: ca. $50^{\circ} 30^{\prime} \mathrm{N} / 18^{\circ} 49^{\prime} \mathrm{E}$ ). The stream bed is silty. The study 
Table 1. Algae taxa occurrence in Dęby Boruszowickie water bodies during sampling with comparison to the species occurrence in Poland (rare - noted up to three times from Poland, often - noted four or more times from Poland).

\begin{tabular}{lc}
\hline Taxa & Octob \\
2008 \\
& Cyanophyta \\
Oscillatoria sp. Vaucher ex Gomont & + \\
Phormidium sp. Kützing ex Gomont & +
\end{tabular}

Planktothrix agardhii (Gomont) Anagnostidis and Komárek

Heterokontophyta

Bacillariophyceae

Achnanthes sp. Bory de Saint-Vincent

Cyclotella sp. (Kützing) Brébisson

Eunotia bilunaris (Ehrenberg) Schaarschmidt

Eunotia exigua (Brébisson ex Kützing) Rabenhorst

Eunotia sp. Ehrenberg

Gomphonema parvulum (Kützing) Kützing

Navicula sp. Bory de Saint-Vincent

Nitzschia obtusa W.Smith

Nitzschia palea (Kützing) W.Smith

Pinnularia cf. ferrophila K. Krammer

Pinnularia nodosa (Ehrenberg) W.Smith

Pinnularia viridis (Nitzsch) Ehrenberg

Heterokontophyta

Xanthophyceae

Characiopsis subulata var. ensiformis (Hermann) Lemmermann

Tribonema sp. Derbès \& Solier

$+$

Euglenophyta

Euglenophyceae

Euglena agilis H.J. Carter

Euglena archaeoviridis B. Zakrys and P.L. Walne

Euglena archaeoplastidiata M. Chadefaud

Euglena hemichromata Skuja

Euglena mutabilis F. Schmitz

Euglena sp. Ehrenberg

Lepocinclis spirogyroides Marin \& Melkonian

Euglena viridis (O.F. Müller) Ehrenberg

Lepocinclis fusca (Klebs) Kosmala and Zakrys

Lepocinclis acus (O.F.Müller) Marin \& Melkonian

Lepocinclis oxyuris (Schmarda) Marin and Melkonian

Lepocinclis ovum (Ehrenberg) Lemmermann

Monomorphina pyrum (Ehrenberg) Mereschkowsky

Petalomonas mediocanellata Stein

Phacus acuminatus Stokes

Phacus angustus Drezepolski

Phacus caudatus Hübner

Phacus curvicauda Svirenko

Phacus ichthydion Pochmann

Phacus indicus Skvortzov

Phacus inflexus (I. Kiselev) Pochmann

Phacus longicauda var. tortus Lemmermann

Phacus orbicularis Hübner

Phacus obolus Pochmann

Phacus parvulus Klebs

Phacus pleuronectes (O.F. Müller) Nitzsch

Phacus pusillus Lemmermann

Phacus unguis Pochmann

Trachelomonas bacillifera Playfair

Trachelomonas cervicula Stokes

Trachelomonas hispida (Perty) F.Stein

Trachelomonas oblonga Lemmermann

Trachelomonas perforata Awerinzew

Trachelomonas volvocinopsis Swirenko

\begin{tabular}{|c|c|c|c|c|c|}
\hline & & & + & & Often \\
\hline & + & & & & Often \\
\hline & + & & & & Often \\
\hline & + & & & & Often \\
\hline+ & & & & & Often \\
\hline & + & & + & & Often \\
\hline & & + & & & Often \\
\hline+ & & & + & & Often \\
\hline+ & & + & + & + & Often \\
\hline & & & + & & Rare \\
\hline & + & & & & Often \\
\hline $\begin{array}{l}+ \\
\text { hyvta }\end{array}$ & + & + & + & + & Often \\
\hline
\end{tabular}

\begin{tabular}{ccccc} 
May & July & June & October & $\begin{array}{c}\text { Reported from } \\
2009\end{array}$ \\
2010 & 2011 & 2011 & Poland \\
\hline
\end{tabular}

(1)

Often

Often

Often

Often

Often

Often

Often

Often

Often

Often

Rare

Often

Often

\begin{tabular}{|c|c|c|c|c|c|}
\hline & & + & & & $\begin{array}{l}\text { Often } \\
\text { Rare }\end{array}$ \\
\hline \multirow[t]{2}{*}{+} & + & & & \multirow[t]{2}{*}{+} & Rare \\
\hline & + & & + & & Often \\
\hline \multirow[t]{2}{*}{+} & & + & + & \multirow[t]{3}{*}{+} & Often \\
\hline & & + & + & & Often \\
\hline \multirow[t]{2}{*}{+} & & & & & Often \\
\hline & + & + & + & & Often \\
\hline \multirow[t]{6}{*}{+} & & & & & Often \\
\hline & & & + & & Often \\
\hline & & + & & & Often \\
\hline & + & & & & Often \\
\hline & & + & + & & Often \\
\hline & & & + & & Rare \\
\hline \multirow{2}{*}{$\begin{array}{l}+ \\
+\end{array}$} & & & + & + & Often \\
\hline & & & & & Rare \\
\hline \multirow{4}{*}{$\begin{array}{l}+ \\
+\end{array}$} & + & + & + & + & Often \\
\hline & & & + & + & Often \\
\hline & + & & & & Rare \\
\hline & + & & & & Rare \\
\hline \multirow[t]{2}{*}{+} & & & & & Rare \\
\hline & + & & & & Often \\
\hline \multirow[t]{3}{*}{+} & & & & & Often \\
\hline & + & & & & Rare \\
\hline & + & + & + & & Often \\
\hline \multirow[t]{5}{*}{+} & & & & & Often \\
\hline & + & & & & Rare \\
\hline & + & & & & Rare \\
\hline & + & + & & & Often \\
\hline & + & & & & Often \\
\hline \multirow[t]{4}{*}{+} & + & & & + & Often \\
\hline & + & & & & Often \\
\hline & + & & & & Rare \\
\hline & + & & & & Often \\
\hline
\end{tabular}


Table 1. (Contd.)

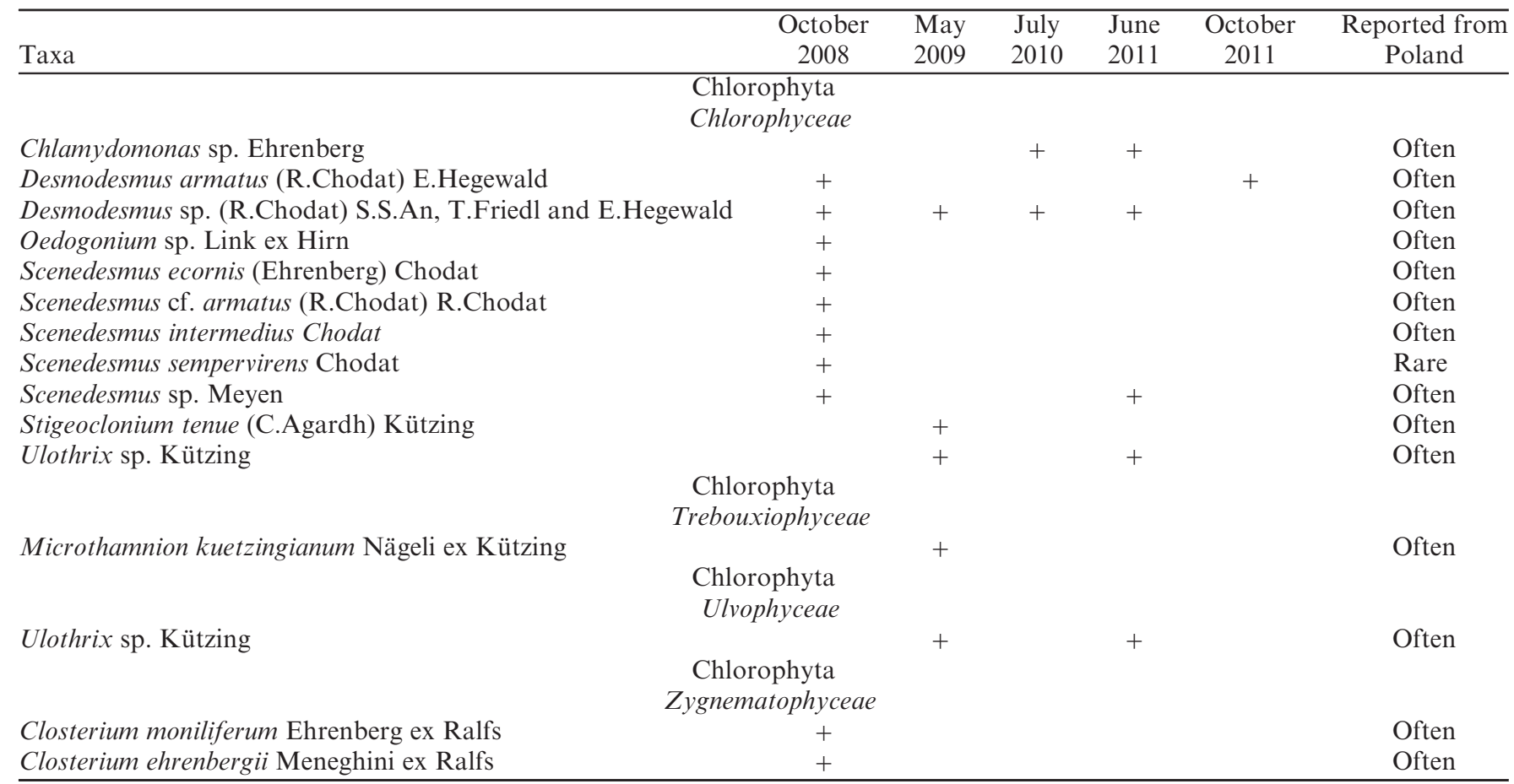

stream is in the Stoła River basin, which has the annual discharge of $1.46 \mathrm{~m}^{3} . \mathrm{s}^{-1}$ (Program of the Environmental Protection for the Tarnowskie Góry community). Part of the oxbow borders the peat bog. The fieldwork was done during the 2008, 2009, 2010 and 2011 vegetation seasons, together with studies on the occurrence of carnivorous Utricularia in this area. Samples for taxonomic research were taken once a year (except in 2011 when sampling was done twice) using a plankton net $(0.25 \mathrm{~mm}$ mesh $)$ and a big pipette (phytobenthos). The samples were placed in $35 \mathrm{ml}$ plastic containers and refrigerated. Fresh samples or samples fixed with $4 \%$ formaldehyde were observed with a Nikon ECLIPSE 600 light microscope with Nomarski phase contrast. The collected water samples were transported to the W. Szafer Institute of Botany (Polish Academy of Sciences) in Cracow, where they were analyzed as previously described (Wołowski et al., 2011).

\section{Chemical analysis of water samples}

Inductively coupled plasma mass spectrometry (ICPMS) (ELAN 6100, Perkin Elmer) (PN-EN ISO 99631:2001) as well as titration methods (PN-ISO 9297:1994; PN-EN ISO 17294-1:2007) were applied to measure the chemical composition of samples. The spectrometer was calibrated to the ICP multi-element standard (Merck).

\section{Results}

Water chemistry analyses showed the following

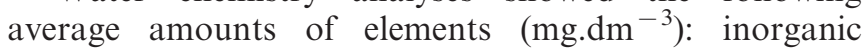
C 78.17, N 7.41, P 0.45, S 151.03, K 36.07, Fe 0.86,
Mg 8.71, Mn 0.26, Ca 123.10. The amounts of heavy metals and metalloids such as $\mathrm{Cr}, \mathrm{Ni}, \mathrm{Cu}, \mathrm{Zn}, \mathrm{Ag}, \mathrm{Hg}$, As and $\mathrm{Se}$ did not exceed the relevant norms. For $\mathrm{Cd}$ $\left(0.06 \mathrm{mg} . \mathrm{dm}^{-3}\right)$ the upper limit was exceeded by a factor of 16 (Polish standard) or 40 (US EPA standard), for $\mathrm{Pb}\left(0.05 \mathrm{mg} . \mathrm{dm}^{-3}\right)$ by a factor of 7 (US EPA standard) and for $\mathrm{Zn}\left(1.06 \mathrm{mg} . \mathrm{dm}^{-3}\right)$ by a factor of 10 (US EPA standard). The concentration of $\mathrm{Tl}\left(0.24 \mathrm{mg}_{\mathrm{dm}}{ }^{-3}\right)$ exceeded the surface-water limits most spectacularly: by a factor of 120 under both Polish and US EPA standards (Rozporządzenie Ministra Środowiska z dn. 9 listopada 2011 r.; US EPA Water Quality Standards, 2013). In the group of biogenic substances, the upper limits were exceeded for $\mathrm{NO}_{3}^{-}$at $7.15 \mathrm{mg} . \mathrm{dm}^{-3}$ (Polish standard $\leq 5 \mathrm{mg} . \mathrm{dm}^{-3}$ ) and for $\mathrm{PO}_{4}^{3-}$ at $0.45 \mathrm{mg} \cdot \mathrm{dm}^{-3}$ (Polish standard $\left.\leq 0.31 \mathrm{mg} \cdot \mathrm{dm}^{-3}\right)$. Other water parameters were as follows: $\mathrm{pH}$ 7.0-7.5, electrical conductivity $1.04 \mathrm{mS} . \mathrm{cm}^{-1}$ and redox potential (Eh) $258 \mathrm{mV}$.

We identified 66 algal taxa representing five phyla (Table 1). The euglenophytes of Graniczna Woda stream showed great diversity, including 9 species of Euglena, 5 of Trachelomonas, 15 of Phacus, 4 of Lepocinclis, and one each of Monomorphina and Petalomonas (see Fig. 2). Among the other algal groups were 3 taxa of Cyanophyceae, 2 of Xanthophyceae, 14 of Bacillariophyceae and 15 of green algae (Chlorophyceae). The euglenophytes dominated among the observed algae in every sampling year, and they also were the group with the highest diversity, numbering 37 taxa. Some of them are taxa rarely noted from Poland: Euglena archaeoviridis B. Zakrys \& P.L. Walne, Euglena archaeoplastidiata M. Chadefaud, Petalomonas mediocanellata Stein, Phacus angustus Drezepolski, Phacus ichthydion 

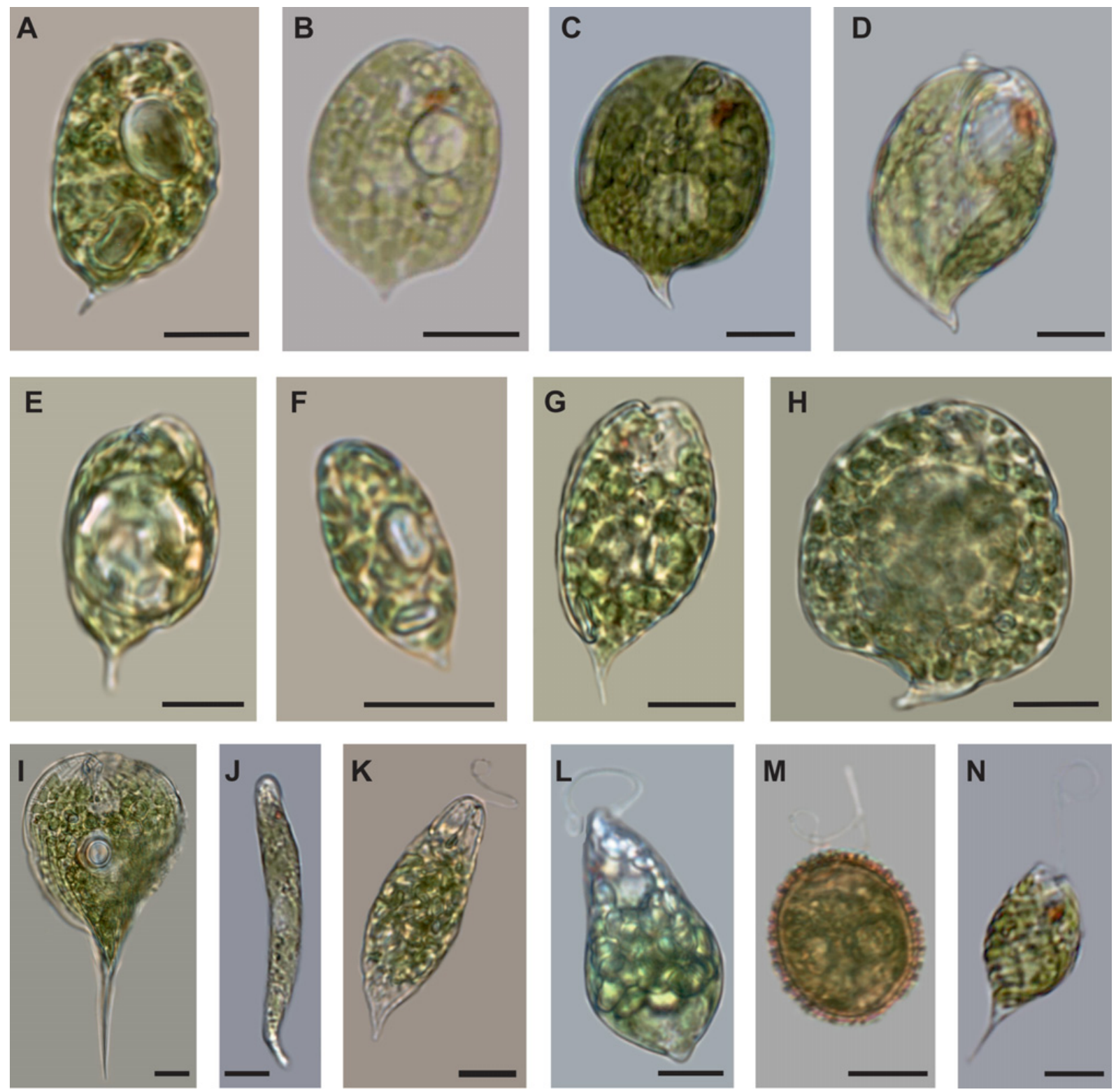

Fig. 2. Euglenophytes documented in samples from Graniczna Woda stream: (A) Phacus indicus, (B) Phacus acuminatus, (C) Phacus alatus, (D) Phacus curvicauda, (E) Phacus obolus, (F) Phacus parvulus, (G) Phacus caudatus, (H) Phacus unguis, (I) Phacus longicauda var. tortus, (J) Euglena mutabilis, (K) Euglena hemichromata, (L) Euglena archaeoviridis, (M) Trachelomonas bacillifera, (N) Monomorphina pyrum. Scale bar $=10 \mu \mathrm{m}$.

Pochmann, Phacus indicus Skvortzow, Phacus inflexus (Kiselev) Pochmann, Phacus obolus Pochmann, Phacus pusillus Lemmermann, Phacus unguis Pochmann and Trachelomonas perforata Awerinzew. The other determined algal taxa are often reported from contaminated waters.

In the area we examined, the water chemistry analyses clearly indicated contamination with biogenic compounds and heavy metals $(\mathrm{Tl}, \mathrm{Cd}, \mathrm{Zn}$ and $\mathrm{Pb})$. This is the first time so many Phacus taxa (15) have been recorded in such a contaminated habitat; Phacus caudatus Hübner, Phacus curvicauda Svirenko and Phacus parvulus Klebs were recorded repeatedly throughout the study. Among the euglenas, Euglena mutabilis F. Schmitz, Euglena viridis
(O.F. Müller) Ehrenberg, E. archaeoplastidiata Chadefaud and Euglena agilis H.J. Carter were constant in the study area. E. agilis occurred en masse in the pallmeloid stage at sampling time in summer 2011. Trachelomonas hispida (Perty) F. Stein was noted in almost every studied sample. Diatoms were equally represented, and Nitzschia palea (Kützing) W. Smith and Pinnularia viridis (Nitzsch) Ehrenberg were noted in every sample. Among the 15 Chlorophyceae taxa the one most commonly noted was Desmodesmus sp. We observed that the shape and arrangement of the chloroplasts in E. viridis and E. mutabilis varied and did not always fit the classical description, and that the dimensions of euglenophyte specimens were at their lower limits. 


\section{Discussion}

Previously we studied algal flora in the JeleniakMikuliny Reserve, situated in the same large forest complex as Dęby Boruszowickie. The area of the Jeleniak-Mikuliny reserve consists of two shallow, overgrown water ponds lying in the lowland between two sand dunes. In this reserve, we found 96 algal taxa [Cyanophyceae (4) Bacillariophyceae (20), Chrysophyceae (1), Raphidophyceae (1), Xanthophyceae (1), Cryptophyceae (2), Dinophyceae (1), Euglenophyceae (24), Chlorophyceae (19), Zygnematophyceae (27)] and 11 morphotypes of chrysophyte stomatocysts (Wołowski et al., 2013a). The algal flora of polluted Graniczna Woda stream was poorer, with 66 species. It is known that heavy metal pollution alters algal diversity and also community structure. Different species may be more or less tolerant to pollution and some may dominate in a polluted environment (Say and Whitton, 1980; Whitton et al., 1981; Podda et al., 2013; Trzcińska and PawlikSkowrońska, 2013). Some cyanobacteria of the genera Oscillatoria, Phormidium, Plectonema and Schizothrix are often abundant in alkaline waters polluted by heavy metal compounds (Say and Whitton, 1980; Whitton et al., 1981). Thus we might expect such taxa to be very abundant in the alkaline, metal-polluted water of Graniczna Woda stream, but we observed Oscillatoria sp. and Phormidium sp. during only one season. The low occurrence of filamentous cyanobacteria may also be related to a lack of $\mathrm{N}$ limitation (as the mean $\mathrm{N}$ : mean $\mathrm{P}$ was 16.4:1 which is very close to the Redfield ratio of 16:1) (see Reynolds, 1984), or to the presence of other organic compounds that were present in the studied water.

The high diversity of euglenoids in Graniczna Woda stream indicates high tolerance of $\mathrm{Tl}$ by these algae. Years of research on euglenophytes have shown that they are remarkably tolerant to various kinds of pollution with heavy metals such as $\mathrm{Fe}, \mathrm{Zn}, \mathrm{Cu}, \mathrm{Cd}, \mathrm{Mn}, \mathrm{Pb}, \mathrm{Ni}$ and $\mathrm{Al}$ (Albergoni et al., 1980; Tam et al., 1981; Fasulo et al., 1983; Walne and Kivic, 1990). They have also been found in waters polluted with diesel oil (Dennington et al., 1975), phenol (Pawlitz and Werner, 1978) and herbicides and insecticides (Poorman, 1973; Butler, 1977), and can survive in highly radioactive water (Lackley, 1968). Euglenophytes are also found living under very high salinity, for example, in Great Salt Lake (Jones, 1944).

Several features help euglenophytes to survive in an unfavorable environment, such as fast reproduction (division), formation of cysts (Hindák et al., 2000) and mixotrophy. Euglenophytes thrive very well in eutrophic water and as a consequence they are often used as bioindicators of water contamination (Starmach, 1983; Sládeček and Sládečková, 1996; Wołowski, 1998, 2011, Wołowski and Hindák, 2005). They usually inhabit $\alpha$-mesosaprobic and polysaprobic waters.

The contamination of the studied stream with organic phosphates and nitrates explains the abundant occurrence of euglenophytes. It is known that high concentrations of heavy metals limit a site's availability to different groups of organisms but in this case they apparently had no major effect on the algal taxa that occurred in Dęby Boruszowickie.

It is generally known that acidophilic E. mutabilis (Lane and Burris, 1981) and Euglena gracilis (Cook, 1968) are able to grow in highly polluted habitats. E. mutabilis colonizes highly acidified waters, tolerates $\mathrm{pH}$ of $c a$. 1 , and can be dominant among the eukaryotes in habitats such as the metal-contaminated ponds of the Smoking Hills region of the Canadian Arctic (Tam et al., 1981; Havas and Hutchinson, 1983) and acidic post-mining ponds contaminated with heavy metals (Wołowski et al., 2008, 2013b). In the investigated area of Dęby Boruszowickie, E. mutabilis was present but did not develop en masse. Probably its growth was limited by the high $\mathrm{pH}(7-7.5)$ of the water. Our results confirm the higher tolerance spectrum of E. mutabilis. Presumably the very low $\mathrm{pH}$ of post-mining ponds also limits the growth of euglenophytes, such as Phacus species, which prefer slightly acidic or neutral water.

We found no literature data about the occurrence of these Phacus species in waters contaminated with heavy metals, including Tl. Ph. caudatus and Ph. curvicauda are common, well-known species that occur in waters polluted with organic compounds. There are somewhat fewer records published for Ph. parvulus, which occurred in Graniczna Woda stream throughout the studied period. That this small organism covered only by a pellicle can thrive in such an inhospitable habitat is an intriguing finding.

Future studies should determine whether the algae of Graniczna Woda stream accumulate heavy metals or possess physiological adaptations endowing them with a mechanism to effectively exclude harmful heavy metals.

Acknowledgements. We would like to thank Michael Jacobs for improving the English version of the manuscript. For this research, K.W. received funding from the Polish Ministry of Science and Higher Education/National Science Centre (grant N N304 220135), K.W. and M.Ł. received funding from the statutory fund of the Institute of Botany, Polish Academy of Sciences, and J.A. received funding from the National Science Centre (grant DEC-011/03/B/NZ9/00952). B.J. Płachno gratefully acknowledges granting of a Scholarship for Outstanding Young Scientists from the Minister of Science and Higher Education. The authors are very grateful to the reviewers for their valuable comments on the manuscript.

\section{References}

Albergoni V., Piccini E. and Coppellotti O., 1980. Response to heavy metals in organisms. I Excretion and accumulation of physiological and non-physiological metals in Euglena gracilis. Comp. Biochem. Phys., 67c, 121-127.

Al-Najar H., Kaschl A., Schultz R. and Romheld V., 2005. Effect of thallium fractions in the soil and pollution origins on $\mathrm{Tl}$ uptake by hyperaccumulator plants: a key factor 
for the assessment of phytoextraction. Int. J. Phytorem., 7, $55-67$.

Arzate S.G. and Santamaria A., 1998. Thallium toxicity. Toxicol. Lett., 99, 1-13.

Augustynowicz J., Tokarz K., Baran A. and Płachno B.J., 2014. Phytoremediation of water polluted by $\mathrm{Tl}, \mathrm{Cd}, \mathrm{Zn}$ and $\mathrm{Pb}$ with the use of macrophyte Callitriche cophocarpa. Arch. Environ. Contam. Toxicol., 66, 572-581.

Avery S.V., Codd G.A. and Gadd G.M., 1991. Caesium accumulation and interactions with other monovalent cations in the cyanobacterium Synechocystis PCC6803. J. Gen. Microbiol., 137, 405-413.

Babić M., Radić S., Cvjetko P., Roje V., Pevalek-Kozlina B. and Pavlica M., 2009. Antioxidative response of Lemna minor plants exposed to thallium(I)-acetate. Aquat. Bot., 91, 166-172.

Babula P., Adam V., Opatrilova R., Zehnalek J., Havel L. and Kizek R., 2008. Uncommon heavy metals, metalloids and their plant toxicity; a review. Environ. Chem. Lett., 6, 189-213.

Butler G.L., 1977. Algae and pesticides. Residue Rev., 99, 19-62.

Cook J.R., 1968. The cultivation and growth of Euglena. In: Buetow D.E. (ed.), The Biology of Euglena, Vol. II, Academic Press, New York, 243-314.

Dennington V.N., George J.J. and Wyborn C.H.E., 1975. The effects of oils on growth of freshwater plankton. Environ. Pollut., 8, 233-237.

Dmowski K., Kozakiewicz A. and Kozakiewicz M., 1998. Small mammal population and community under conditions of extremely high thallium contamination in the environment. Ecotoxicol. Environ. Safety, 41, 2-7.

Fasulo M.P., Bassi M. and Donini A., 1983. Cytotoxic effects of hexavalent chromium in Euglena gracilis. II. Physiological and ultrastructural studies. Protoplasma, 114, 143-153.

Fleischer M. 1997. Thallium. Anal. Hazard. Subst. Biol. Mater., 5, 163-179.

Havas M. and Hutchinson T.C., 1983. The Smoking Hills: natural acidification of an aquatic ecosystem. Nature, 301, 23-27.

Hindák F., Wołowski K. and Hindakowa A., 2000. Cysts and their formation in some neustonic Euglena species. Ann. Limnol. - Int. J. Lim., 36, 83-93.

Jones D.T., 1944. Two protozoans from Great Salt Lake. Bull. Univ. Utah Biol. Ser., 8, 3-10.

Kabata-Pendias A. and Mukherjee A.B., 2007. Trace Elements from Soil to Human, Springer-Verlag, Berlin, Heidelberg, $345-350$.

Lackey J.B., 1968. Ecology of Euglena. In: Buetow D.E. (ed.), The Biology of Euglena, Vol. I: Academic Press, New York, $28-44$.

Lane A.E. and Burris J.E., 1981. Effects of environmental pH on the internal $\mathrm{pH}$ of Chlorella pyrenoidosa, Scenedesmus quadricauda, and Euglena mutabilis. Plant Physiol., 68, 439-442.

Leblanc M., Petit D., Deram A., Robinson B.H. and Brooks R.R., 1999. The phytomining and environmental significance of hyperaccumulation of thallium by Iberis intermedia from southern France. Econ. Geol., 94, 109-114.

Léonard A. and Gerber G.B., 1997. Mutagenicity, carcinogenicity and teratogenicity of thallium compounds. Mutat. Res., $387,47-53$.
Lustigman B., Lee L.H., Morata J. and Khan F., 2000. Effect of thallium on the growth of Anacystis nidulans and Chlamydomonas reinhardtii. Bull. Environ. Contam. Toxicol., 64, 565-573.

Pawlitz H. and Werner D., 1978. Differential elimination of phenol by diatoms and other unicellular algae from lower concentrations. Bull. Environ. Contam. Toxicol., 20, 303-312.

Peter A.L.J. and Viraraghavan T., 2005. Thallium: a review of public health and environmental concerns. Environ. Int., 31, 493-501.

PN-EN ISO 9963-1:2001. Water Quality - Determination of Alkalinity - Part 1: Determination of Total and Composite Alkalinity, Polish Committee for Standardization, Warsaw, Poland.

PN-EN ISO 17294-1:2007. Water Quality - Application of Inductively Coupled Plasma Mass Spectrometry (ICP-MS) - Part 1: General Guidelines. Polish Committee for Standardization, Warsaw, Poland.

PN-ISO 9297:1994. Water Quality - Determination of Chloride Silver Nitrate Titration with Chromate Indicator (Mohr's Method), Polish Committee for Standardization, Warsaw, Poland.

Podda F., Medas D., De Giudici G., Ryszka P., Wołowski K. and Turnau K., 2013. Zn biomineralization processes and microbial biofilm in a metal-rich stream (Naracauli, Sardinia). Environ. Sci. Pollut. Res., 21, 6793-6808.

Poorman A.R., 1973. Effects of pesticides on Euglena gracilis. I. Growth studies. Bull. Environ. Contam. Toxicol., $10,25-28$.

Program of the Environmental Protection for the Tarnowskie Góry community for the years 2012-2015 with the prospect for 2016-2019, Accessed online 20 January 2015, http:// www.tarnowskiegory.pl/files/environments/696/ poS_tarnowskie_gory.pdf (in Polish).

Ralph L. and Twiss M.R., 2002. Comparative toxicity of thallium (I), thallium (III), and cadmium (II) to the unicellular alga Chlorella isolated from Lake Erie. Bull. Environ. Contam. Toxicol., 68, 261-268.

Reczyńska-Dutka M., 1986. Transport of heavy metals in three differently polluted surface waters in Silesia (Southern Poland). Acta Hydrobiol., 28, 279-291.

Reynolds C.S., 1984. The Ecology of Freshwater Phytoplankton, Cambridge University Press, Cambridge, 178-180.

Rozporządzenie Ministra Środowiska z dn. 9 listopada 2011 r. w sprawie sposobu klasyfikacji stanu jednolitych wód powierzchniowych oraz środowiskowych norm jakości dla substancji priorytetowych. Dziennik Ustaw nr 257, poz. 1545.

Say P.J. and Whitton B.A., 1980. Changes in flora down a stream showing a zinc gradient. Hydrobiologia, 76, 255-262.

Sládeček V. and Sládečková A., 1996. Atlas of Aquatic Organisms with Respect to Water Supply, Surface Waters and Wastewater Treatment Plants, Česká vědeckotechnická vodohospodářská společnost v Agrospoji, Praha, 351 p.

Starmach K., 1983. Euglenophyta - Eugleniny, Flora Słodkowodna Polski. Polska Akademia Nauk, Instytut Botaniki, Vol. 3, Polskie Wydawnictwo Naukowe, Kraków, $563 \mathrm{p}$.

Tam D., Nakatsu C. and Hutchinson T.C., 1981. Multiple metal tolerances and co-tolerances in algae. In: Heavy Metals in the Environment International Conference, Amsterdam, 300-304. 
Trzcińska M. and Pawlik-Skowrońska B., 2013. Differences in $\mathrm{Zn}$ and $\mathrm{Pb}$ resistance of two ecotypes of the microalga Eustigmatos sp. inhabiting metal loaded calamine mine spoils. J. Appl. Phycol., 25, 277-284.

Turner A. and Furniss O., 2012. An evaluation of the toxicity and bioaccumulation of thallium in the coastal marine environment using the macroalga, Ulva lactuca. Mar. Pollut. Bull., 64, 2720-2724.

United States Environemnatl Protection Agency (2013) Water Quality Standards, section 304(a) Criteria for Priority Toxic Pollutants, Accessed online 10 June 2013, http://www.ecfr.gov/cgi-bin/text-idx?c $=$ ecfr\&SID $=$ 0d9ad6456ca41c8adb0d2377dd28f853\&rgn $=$ div5\&view $=$ text\&node $=40: 23.0 .1 .1 .18 \&$ idno $=40 \# 40: 23.0 .1 .1 .18 .3 .16 .1$.

van der Ent A., Baker A.J.M., Reeves R.D., Pollard A.J. and Schat H., 2013. Hyperaccumulators of metal and metalloid trace elements: facts and fiction. Plant Soil, 362, 319-334.

Walne P.L. and Kivic P.A., 1990. 15. Phylum Euglenida. In: Margulis L., Corliss J.O., Melkonian M. and Chapmann D.J. (eds.), Handbook of Protoctista, Jones and Bartlett, Boston, 270-287.

Whitton A., Gale N.L. and Wixson B.G., 1981. Chemistry and plant ecology of zinc-rich wastes dominated by blue green algae. Hydrobiologia, 83, 331-341.

Wierzbicka M., Szarek-Łukaszewska G. and Grodzińska K., 2004. Highly toxic thallium in plants from the vicinity of Olkusz (Poland). Ecotox. Environ. Safety, 59, 84-88.
Wołowski K., 1998. Taxonomic and environmental studies on Euglenophytes of the Kraków Częstochowa Upland (Southern Poland). Fragm. Flor. Geobot., Suppl., 6, 1-192.

Wołowski K., 2011. Phylum Euglenophyta (Euglenoids). In: John D.M., Whitton B.A. and Brook A.J. (eds.), The freshwater Algal Flora of the British Isles. An Identification Guide to Freshwater and Terrestrial Algae, Second edn, Cambridge University Press, Cambridge, 181-239.

Wołowski K. and Hindák F., 2005. Atlas of Euglenophytes, VEDA, Publishing House of the Slovak Academy of Science, Bratislava, $136 \mathrm{p}$.

Wołowski K., Turnau K. and Henriques F.S., 2008. The algal flora of an extremely acidic, metal-rich drainage pond of Săo Domingos pyrite mine (Portugal). Cryptogamie Algol., 29, 313-324.

Wołowski K., Piątek J. and Płachno B.J., 2011. Algae and stomatocysts associated with carnivorous plants. First report of chrysophyte stomatocysts from Virginia, USA. Phycologia, 50, 511-519.

Wołowski K., Piątek J. and Płachno B.J., 2013a. Chrysophycean stomatocysts associated with the carnivorous plants (genus Utricularia) from Jeleniak-Mikuliny Nature Reserve. Oceanol. Hydrobiol. Stud., 44, 398-405.

Wołowski K., Uzarowicz Ł., Łukaszek M. and PawlikSkowrońska B., 2013b. Diversity of algal communities in acid mine drainages of different physico-chemical properties. Nova Hedwigia, 97, 117-137. 